\title{
Kepuasan Pernikahan dan Kematangan Emosi pada Suami dengan Istri Bekerja
}

\author{
Nurhikmah \\ Hepi Wahyuningsih \\ Fitri Ayu Kusumaningrum
}

\begin{abstract}
Program Studi Psikologi, Fakultas Psikologi dan Ilmu Sosial Budaya
Universitas Islam Indonesia, Yogyakarta
\end{abstract}

\begin{abstract}
This study explore the correlation between marital satisfaction and emotional maturity among husbands with working wife. The hypothesis to be tested is there is positive correlation between marital satisfaction and emotional maturity. Participants in this research were husbands aged 20-70 years old with working wife. The Indonesian Moslem Marital Quality Scale from Wahyuningsih (2013) and emotional maturity scale from Singh and Bhargava (Kathuria, 2014) were used in this study. The data was analyzed by product moment analysis technique. Result showed that marital satisfaction was significantly correlated with emotional maturity $(r=0,223$, $\mathrm{p}<0.05$ ).
\end{abstract}

Key words: emotional maturity, marital satisfaction, husband with working wife

Abstrak. Penelitian ini bertujuan untuk mengeksplorasi hubungan antara kepuasan pernikahan dan kematangan emosi pada suami dengan istri bekerja. Hipotesis yang akan diuji yaitu ada korelasi positif antara kepuasan pernikahan dan kematangan emosi. Responden pada penelitian ini yaitu suami dengan istri bekerja yang berusia 20-70 tahun. Skala yang digunakan terdiri dari Skala Kualitas Pernikahan Muslim dari Wahyuningsih (2013), dan skala kematangan sosial dari Singh dan Bhargava (Kathuria, 2014). Data dianalisis dengan Teknik korelasi product moment. Hasil menunjukkan bahwa terdapat korelasi positif antara kepuasan pernikahan dengan kematangan $\operatorname{emosi}(r=0,223, p<0.05)$.

Kata kunci : kematangan emosi, kepuasan pernikahan, suami dengan istri bekerja

Menikah pada dasarnya merupakan salah satu fitrah manusia sebagaimana Tuhan telah menjadikan manusia berpasangpasangan. Cherlin menyebutkan bahwa hampir 90\% individu melangsungkan pernikahan, setidaknya sekali dalam seumur hidup (Sanders, 2010). Menurut UU Republik
Indonesia No.1 th 1947 tentang perkawinan Bab 1 (Dasar Perkawinan) pasal 1 menyebutkan bahwa perkawinan ialah ikatan lahir batin antara seorang pria dengan seorang wanita sebagai suami istri dengan tujuan membentuk keluarga (rumah tangga) yang bahagia dan kekal berdasarkan Ketuhanan

Korespondensi: Hepi Wahyuningsih. Email : hepi.wahyuningsih@uii.ac.id 
Yang Maha Esa.

Secara umum, pernikahan sendiri didefiniksikan sebagai ikatan jangka panjang yang memiliki kekuatan sosial dan melibatkan kerjasama ekonomi, sosial, dan reproduksi antarpasangan (Regan, 2011). Pernikahan bisa diartikan sebagai penyatuan dua keluarga dan kesempatan untuk mengembangkan hubungan yang lebih intim dalam berbagi hubungan (Olson \& Defrain, 2014). Walgito (2004) menjelaskan bahwa pernikahan merupakan ikatan lahir batin antara seorang pria dan seorang wanita sebagai suami istri dengan tujuan membentuk keluarga (rumah tangga yang bahagia). Olson \& Defrain (2014) menyebutkan pernikahan juga merupakan suatu komitmen emosional antara dua orang yang diakui secara hukum untuk saling berbagi keintiman, perasaan dan hubungan seksual, berbagi tugas serta sumber ekonomi.

Tujuan dilaksanakan pernikahan yaitu untuk membentuk keluarga yang sakinah, mawaddah, wa rahamah (QS. Ar Ruum : 21). Disisi lain, memang tujuan pernikahan itu sendiri berbeda pada tiap pasangan. Itulah yang membedakan pasangan satu dengan pasangan yang lainnya. Tujuan pernikahan menjadi fondasi suksesnya sebuah pernikahan.

Menurut Walgito (2004) kepuasan pernikahan tidak hanya ditandai oleh orang yang menjalin relasi pernikahan tetapi dari sejauh mana pasangan suami istri dapat merasakan kepuasan pernikahan dengan saling memenuhi kebutuhan fisik, emosional, dan psikologis. Spanier dan Lewis (Callan \& Noller, 1987) menjelaskan bahwa faktor yang mempengaruhi kepuasan pernikahan adalah (1) faktor premarital yakni kesamaan, personal resourcess, dukungan dari orang tua dan temanteman-teman, (2) faktor sosioekonomi yakni kesejahteraan ekonomi, status pekerjaan istri, ukuran rumah, kedekatan komunitas, dan faktor hubungan interpersonal.

Setiap pasangan yang menikah umumnya mengharapkan dan menginginkan pernikahan yang membahagiakan dan memuaskan. Namun ironisnya, tidak semua pasangan merasakan kebahagiaan dan kepuasan pernikahan terhadap pernikahannya. Kepuasan pernikahan menurut Hawkins (Pujiastuti \& Retnowati, 2004) merupakan perasaan subjektif yang dirasakan pasangan suami istri berkaitan dengan aspek-aspek yang ada dalam suatu pernikahan, seperti rasa bahagia, puas, serta pengalaman-pengalaman yang menyenangkan bersama pasangannya yang bersifat individual.

Idealnya, kepuasan pernikahan dirasakan oleh setiap pasangan suami istri, baik yang usia pernikahannya masih muda atau bahkan yang usia pernikahannya sudah bertahun-tahun, karena kepuasan pernikahan merupakan sesuatu yang penting dalam sebuah pernikahan. Hasil penelitian menunjukkan bahwa ketika 20-24 tahun pertama usia pernikahan, semakin lama pasangan menikah, maka cenderung semakin kurang puas. Akan tetapi, ketika 35-44 tahun usia pernikahan, 
sepasang suami istri cenderung lebih puas dibandingkan selama empat tahun pertama usia pernikahan (Papalia, Old, \& Feldman, 2009).

Terdapat banyak masalah untuk mencapai sebuah kepuasan pernikahan salah satunya adalah permasalahan dalam status bekerja pada pasangan baik suami maupun istri. Menurut hasil penelitian yang dilakukan oleh Paputungan (2013) menyatakan bahwa secara keseluruhan suami sebagai subjek merasa kurang puas dengan keintiman fisik pernikahannya, akan tetapi suami yang memiliki istri yang bekerja, akan merasa puas dengan pernikahannya jika mampu menciptakan keterbukaan komunikasi yang terbuka dan konstruktif, dapat menciptakan kepuasan pada faktor kongruensi, komitmen dan keyakinan beragama dalam pernikahan. Penelitian yang dilakukan oleh Rahmaningrum (2013) menyatakan bahwa terdapat perbedaan kepuasan pernikahan yang sangat signifikan antara suami dan istri pada pasangan yang duaduanya bekerja (dual career), suami dan istri pasangan dual career memiliki perbedaan kepuasan pernikahan karena dalam pasangan dual career ketegangan-ketegangan yang dirasakan suami dan istri lebih sering muncul, ketegangan-ketegangan umumnya berasal dari peran-peran yang sering tidak jelas serta adanya tuntutan peran dari lingkungan. Penelitian yang dilakukan oleh Ingrid (1997) menyatakan bahwa istri yang bekerja menurut persepsi suami yakni untuk tujuan ekonomis dan non ekonomis yaitu selain untuk memperoleh penghasilan (ekonomis) juga adanya kebutuhan untuk memperluas wawasan intelektual dan interaksi sosial (non ekonomis), dimana hal ini dipersepsi sama pentingnya oleh suami maupun istri.

Peran wanita saat ini sudah mengalami pergeseran dilihat dari banyaknya jumlah wanita yang bekerja di Indonesia. Menurut Etiawati (2009) seorang wanita yang bekerja berarti memiliki pekerjaan khusus di luar rumah dalam rangka mengaktualisasikan diri dan menekuni suatu bidang tertentu. Adapun jumlah wanita yang bekerja di Indonesia sesuai dengan sensus penduduk pada tahun 2010 yaitu sebanyak 39,5 juta jiwa (badan pusat statistik). Begitupun di Provinsi Daerah Istimewa Yogyakarta, wanita yang bekerja bertambah dalam tahun tahun-tahun terakhir, jumlah pekerja wanita profesional menjadi 66.062 orang pada tahun 2010 (BPPM DIY, 2011).

Penelitian yang dilakukan oleh Niaz dan Hassan (2006) membuktikan bahwa wanita yang bekerja menghabiskan waktu bekerja antara 11-14 jam dalam seharinya. Menurut Rini (Kurnianingtyas, 2009) melalui bekerja, wanita berusaha menemukan arti dan identitas diri, dan pencapaian tersebut mendatangkan rasa percaya diri dan kebahagiaan. Namun, apabila seorang wanita yang juga menjadi seorang istri pasangan yang bekerja otomatis hanya memiliki waktu yang tidak banyak berada di dalam rumah, sehingga intensitas 
waktu untuk bertemu dengan keluarga baik suami maupun anak menjadi berkurang.

Setiap orang tentu ingin pernikahan yang memuaskan dan bahagia. Pada kenyataannya, bukanlah hal yang mudah untuk memelihara dan membina keluarga hingga mencapai taraf kebahagiaan dan kesejahteraan yang diinginkan oleh setiap pasangan suami istri. Mencapai kehidupan pernikahan yang memuaskan diperlukan adanya motivasi yang kuat untuk membina dan mempertahankannya. Hal ini dikarenakan berbagai masalah yang datang menerpa rumah tangga akan membuat pasangan merasakan ketidakpuasan dalam menjalani kehidupan pernikahan (Basri, 2004).

Setiap pasangan sudah tentu mendambakan adanya sebuah pernikahan dalam kehidupan pernikahannya. Namun sejumlah realitas yang menunjukkan bahwa adanya kasus ketidakpuasan pernikahan yang di sebabkan oleh banyak faktor yang tidak jarang berujung pada perceraian. Menurut data terakhir yang diperoleh dari situs BKKBN menyebutkan bahwa jumlah angka perceraian di Indonesia mencapai 200 ribu pertahun selain data tersebut, kementrian Agama RI yang disampaikan oleh Kepala Subdit Kepenghuluan, Anwar Saadi pada Jumat (14/11/2014) menyebutkan bahwa pada tahun 2011, jumlah angka pernikahan 2.319.821 kejadian, jumlah angka cerai 372.577 kejadian, tahun 2012, jumlah angka pernikahan 2.291.265 kejadian, jumlah angka cerai 372.577 kejadian tahun 2013, jumlah angka pernikahan 2.218.130 kejadian, jumlah angka cerai 324.527 kejadian. Hal tersebut memperlihatkan bahwa dalam satu hari rata-rata terjadi 959 kasus perceraian atau 40 kasus perceraian setiap jamnya (BKKBN, 2010).

Untuk mencapai taraf kebahagiaan dan kesejahteraan yang diidam-idamkan oleh setiap pasangan suami istri di perlukan kematangan emosi yang dimiliki setiap pasangan. Salah satu faktor kepuasan pernikahan menurut Walgito (2004) adalah adanya kematangan emosi, bila individu yang telah matang emosinya akan dapat berpikir secara matang, berpikir secara baik, berpikir secara objektif sehingga suami istri dapat melihat permasalahan yang ada dalam keluarga sengan secara baik secara objektif. Individu yang matang emosinya memiliki kemampuan untuk mengontrol emosinya sehingga dapat juga melakukan kontrol terhadap perilakunya (Rakhmat, 2003).

Setiap pasangan idealnya masingmasing memiliki kematangan emosi yang baik. Hasil penelitian Firouzabadi, dkk (2011) menunjukkan bahwa kualitas kepuasan pernikahan yang baik ditandai oleh salah satunya adanya kematangan emosi yang baik. Oleh sebab itu, kematangan emosi merupakan hal yang penting dalam sebuah hubungan pernikahan.

Dari penjelasan di atas dapat disimpulkan bahwa betapa pentingnya suami sebagai kepala rumah tangga dalam sebuah pernikahan idealnya memiliki kematangan 
Nurhikmah, Hepi Wahyuningsih, \& Fitri Ayu Kusumaningrum.

emosi yang baik meskipun memiliki istri yang bekerja sehingga tidak adanya konflik atau hubungan yang berakhir pada perceraian antara suami maupun istri. Dengan kematangan emosi yang dimiliki suami meskipun memiliki istri yang bekerja akan berdampak pada kepuasan pernikahan. Berdasarkan uraian tentang latar belakang tersebut maka peneliti tertarik untuk melakukan penelitian yang ingin mengetahui hubungan antara kematangan emosi dengan kepuasan penikahan pada suami yang memiliki istri bekerja.

\section{Metode}

\section{Subjek penelitian}

Subjek penelitian ini adalah suami yang bekerja yang memiliki istri bekerja, berpendidikan minimal SMU, usia antara 20-70 tahun, minimal memiliki 1 anak serta bersedia menjadi subjek dari penelitian ini.

\section{Metode pengumpulan data}

Penelitian ini menggunakan skala kualitas perkawinan dari The Indonesian Moslem Marital Quality Scale (IMMQS) Wahyuningsih (2013) mengungkap 3 aspek yaitu persahabatan, kepuasan terhadap anak, dan keharmonisan. Skala ini terdiri dari 13 aitem yang semua aitemnya favourable. Tanggapan subjek terhadap aitem-aitem dalam skala ini dikelompokkan menjadi empat yaitu : Hampir Tidak Pernah, Jarang, Sering, Hampir
Selalu. Pemberian nilai untuk pernyataan tersebut adalah hampir Tidak pernah (1) Jarang (2), Sering (3), Hampir selalu (4).

Uji coba reliabilitas skala kepuasan pernikahan menghasilkan koefisien reliabilitas alpha sebesar 0,745. Hal ini menunjukkan bahwa skala kepuasan pernikahan juga dapat dikatakan reliabel sehingga dapat memenuhi syarat untuk digunakan sebagai alat ukur. Sedangkan hasil validitas skala kepuasan pernikahan yang terdiri dari 16 aitem bergerak antara 0,120 sampai 0,587.

Sementara untuk mengungkapkan kematangan emosi, peneliti menggunakan skala dari Singh dan Bhargava (Kathuria 2014), yang mencakup aspek-aspek kematangan emosi emotional unstability, emotional regression, social maladjustment, personality disintergration, lack of independence. Skala ini terdiri dari 48 item yang semua aitemnya unfavourable. Tanggapan subjek terhadap aitem-aitem dalam skala ini dikelompokkan menjadi empat yaitu: Hampir Tidak Pernah, Jarang, Sering, Hampir Selalu. Pemberian nilai untuk pernyataan tersebut adalah Hampir Tidak Pernah (4) Jarang (3), Sering (2), Hampir selalu (1).

Uji reliabilitas skala kematangan emosi menghasilkan koefisien reliabilitas alpha sebesar 0,954. Hal ini menunjukkan bahwa skala kematangan emosi dapat dikatakan reliabel sehingga memenuhi syarat untuk digunakan sebagai alat ukur. Hasil validitas skala kematangan emosi terdiri dari 48 aitem 
bergerak antara 0,102 sampai 0,815.

\section{Hasil}

Uji hipotesis menggunakan teknik korelasi product moment dilakukan guna mengetahui hubungan antara kepuasan pernikahan dengan kematangan emosi pada suami yang memiliki istri bekerja. Berdasarkan hasil analisis data menunjukkan korelasi antara variabel kepuasan pernikahan dengan kematangan emosi $r=0,223$ dan $p=0,015$, menunjukkan bahwa hubungan diantara kedua variabel signifikan. Kemudian berdasarkan analisis koefisien determinasi $\left(r^{2}\right)$ variabel kepuasan pernikahan terhadap kematangan emosi sebesar 49\%.

Berdasarkan analisis tersebut, dapat disimpulkan bahwa hipotesis yang dikemukakan dalam penelitian ini diterima yaitu ada hubungan positif antara kepuasan pernikahan dengan kematangan emosi. Semakin tinggi tingkat kepuasan pernikahan, maka semakin tinggi pula kematangan emosi. Sebaliknya, semakin rendah tingkat kepuasan pernikahan, maka semakin rendah pula kematangan emosinya. Koefesien korelasi ganda (r) yang didapat adalah sebesar 0,223. Dengan demikian dapat dikatakan bahwa selakin terjadi hubungan positif, hubungan yang terbentuk antara kepuasan pernikahan dengan kematangan emosi digolongkan dalam hubungan yang cukup kuat yaitu sebesar 49\%. Selain itu, dari hasil analisis tambahan yang dilakukan, menunjukkan hasil bahwa social maladjustment dan lack of independence menjadi aspek signifikan yang mempengarui kematangan emosi dalam mencapai kepuasan pernikahan.

\section{Pembahasan}

Individu yang mampu mengontrol emosi dan dirinya sendiri dalam menjalani kehidupan dengan lebih mudah untuk menyesuaikan diri dengan lingkungan dengan cara menerima dan membagikan kasih sayang untuk diri sendiri maupun orang lain. Selain itu, individu yang yang emosinya sudah matang tidak cepat terpengaruh oleh rangsangan atau stimulus, baik dari dalam maupun dari luar pribadinya. Saffarpour dan Sarifi (2013) menyebutkan bahwa salah satu faktor penyebab paling penting mencapai kepuasan pernikahan adalah adanya kematangan emosi terkait dengan peran dalam pernikahan.

Umumnya dengan bertambah kematangan emosi seseorang maka akan berkuranglah emosi negatif. Bentuk-bentuk emosi positif seperti rasa sayang, suka, dan cinta akan berkembang jadi lebih baik. Perkembangan bentuk emosi yang positif tersebut memungkinkan individu untuk menyesuaikan diri dengan lingkungan baik dalam kehidupan pernikahan yakni dengan menerima dan membagikan kasih sayang untuk diri sendiri maupun pasangan. Mosavi dan Irafani (2012) menyebutkan bahwa tujuan pernikahan yang diprioritaskan pasangan 
Nurhikmah, Hepi Wahyuningsih, \& Fitri Ayu Kusumaningrum.

dalam pernikahan adalah kepuasan yang berkorelasi dengan kematangan emosi.

Selain itu, pasangan dengan kepuasan pernikahan dalam hubungannya, ia tidak hanya memiliki kematangan emosi yang baik melainkan memiliki hal-hal lain yang dimilikinya, sehingga memunculkan kepuasan pernikahan yang baik. Turner dan Helms (Dariyo, 2004) mengklasifikasikan alasan pernikahan menjadi lima jenis motif, yaitu cinta (love), kecocokan (conformity), legitimasi untuk memenuhi kebutuhan seksual, memperoleh legitimasi status anak, dan merasa siap secara mental untuk menikah.

Diterimanya hipotesis penelitian ini dapat diketahui sesuai asumsi awal bahwa terdapat arah antara kepuasan pernikahan dengan kematangan emosi yang mengindikasikan variabel kematangan emosi menjadi salah satu faktor penting timbulnya kepuasan pernikahan pada suami. Dimana seseorang yang memiliki kematangan emosi yang baik akan mampu untuk mencapai kepuasan pernikahan pada pasangan sehingga memunculkan rasa saling mengerti dan memahami perasaan pasangannya.

\section{Simpulan}

Berdasarkan hasil penelitian yang diperoleh dapat diambil kesimpulan bahwa terdapat korelasi positif yang signifikan antara kepuasan pernikahan dengan kematangan emosi pada suami yang memiliki istri bekerja.
Semakin tinggi kepuasan pernikahan maka semakin tinggi kematangan emosi pada suami yang memiliki istri yang bekerja. Sebaliknya semakin rendah kepuasan pernikahan, maka semakin rendah pula kematangan emosi pada suami yang memiliki istri bekerja.

\section{Saran}

Berdasarkan hasil penelitian dan pembahasan, peneliti mengajukan saran sebagai pertimbangan berbagai pihak terhadap penelitian yang lebih baik di masa yang akan dating, adapun saran dari peneliti yaitu

Bagi suami yang memiliki istri bekerja meningkatkan kepuasan pernikahan dengan cara lebih sering meluangkan waktu menghabiskan waktu bersama-sama untuk bertemu secara intim dengan pasangannya, untuk menghindari munculnya perasaan negatif seperti saling curiga terhadap pasangan yang dapat menimbulkan konflik. Selain itu, suami yang memiliki istri bekerja untuk tetap mempertahankan kematangan emosi dan sebaiknya suami bisa memahami dan saling bekerjasama dalam mengerjakan pekerjaan rumah tangga sehingga dapat mengurangi beban istri diharapkan dengan adanya kerjasama yang baik dapat mewujudkan pernikahan yang lebih harmonis.

Bagi peneliti selanjutnya yang ingin melakukan penelitian dengan pokok bahasan yang sama, penelitian ini dapat menjadi referensi yang dapat membantu dan diharapkan dapat menyempurnakan penelitian 
ini dengan menambah faktor-faktor lainnya yang berpengaruh tentang kematangan emosi serta disarankan agar menambahkan pendekatan dalam penelitian eksperimen untuk memperkuat hasil penelitian karena dengan adanya penambahan metode eksperimen, peneliti mampu memanipulasikan dan mengendalikan satu variabel bebas (independent variable) atau lebih dan melakukan observasi terhadap variabel terikat untuk menemukan variasi yang seiring muncul dengan manipulasi variabel bebas tersebut. Selain itu, penelitian selanjutnya juga perlu dilakukan pada istri yang bekerja.

\section{Daftar Pustaka}

BPPM-DIY. 2011. Profil Gender dan Anak Provinsi Daerah Istimewa Yogyakarta tahun 2011. Yogyakarta: Badan Pemberdayaan Perempuan dan Masyarakat DIY.

Basri, H. (2004). Keluarga Sakinah. Yogyakarta: Pustaka Pelajar.

BKKBN. (2010). Pendewasaan Usia Perkawinan dan Hak-hak Reproduksi bagi Remaja Ind onesia. J a k a r ta: http://cerita.bkkbn.go.id.

Callan, V., \& Noller, P. (1987). Marriage and the Familly. New South Wales: Metheuen Australia Pty Ltd.

Dariyo, A. (2004). Psikologi Perkembangan Remaja. Bogor: Ghalia Indonesia.

Depag, R. I. (1996). Al-Qur'an dan Terjemahannya Departemen Agama Republik Indonesia.
Etiawati. (2009). Karier, Rumah Tangga, Atau Karier dan Rumah Tangga? (Edisi Maret 2009). Jakarta: Tabloid Penabur Jakarta.

Firouzabadi, M. B., \& Hakami, M., \& Mohsen, M. (2011). The Impact of Emotional Matururity Factors on Prediction Marital Satisfaction Among Nurses in Karaj, Earllier title : USChina Education Review, ISSN 1548-6613. Iran: David Publishing.

Ingrid, B. (1997). Persepsi Suami Istri terhadap Istri yang Bekerja sebagai Karyawati Penuh Waktu (Studi pada Pasangan Suami Istri yang bekerja di Jakarta). Skripsi.

Kathuria, J. K. (2014). Managerial Performance in Relation to Emotional Maturity, SelfConfidence and Leadership Skills. Thesis.

Kurnianingtyas, R. (2009). Penerimaan Diri pada Wanita Bekerja Usia Dewasa Dini Ditinjau Dari Status Pernikahan. Skripsi.

Mosavi, S., \& Iravani, M. (2012). A study on relationship between emotional maturity and marital satisfaction. Management Science Letters, 2(3), 927-932.

Niaz. U., \& Hassan. S. (2006). The perception of professional women about their job and its effects on psychosocial well being. J Pak Psych Society. 3(2), 83-85.

Olson. D. H., \& Defrain. J. (2014). Marriage and families: Intimacy, diversity, and strengths. Mc Graw Hill.

Papalia, D. E., Olds, S. W., \& Feldman, R. D. (2009). Human development, Edisi 10, Perkembangan Manusia (Buku 2), diterjemahkan oleh Marwensdy, B. Jakarta : Salemba Humanika.

Paputungan. F. (2013). Kepuasan Pernikahan Suami yang Memiliki Istri Berkarir. Naskah Publikasi. 
Pujiastuti. E., \& Retnowati. S. (2004). Kepuasan Pernikahan dengan Depresi pada Kelompok Wanita Menikah yang Bekerja dan yang Tidak Bekerja. Naskah Publikasi.

Rahmaningrum, P. A. (2013). Perbedaan Kepuasan Pernikahan Antara Suami dan Istri Dual Career. Skripsi.

Rakhmat, J. (2003). Psikologi Komunikasi. Bandung: Remaja Rosdakarya.

Regan, P. (2011). Close Relationships. New York: Routledge.

Sanders. K. M. (2010). Marital Satisfaction Across the Trasnsition to Parenthood. Digital Commons@University of Nebraska-Lincoln. Thesis.

Saffarpour. A., \& Sharifi. A. (2013). Comparing Emotional Maturity and Marital Men Having Healthy and Unhealthy Inference from Their Familly-of-Origin in Tehran Oil Company. Life Science Journal.10(7s). 152-159.

Wahyuningsih, H. (2013). The Indonesian moslem marital quality scale: Development, validation, and reliability. Publisher at Osaka, Japan.

Walgito, B. (2004). Bimbingan dan konseling perkawinan. Yogyakarta: Andi Ofset. 